\title{
NEW DATES FROM SUBMERGED LATE PLEISTOCENE SEDIMENTS IN THE SOUTHERN SEA OF GALILEE, ISRAEL
}

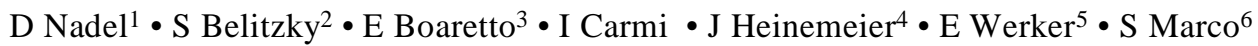

\begin{abstract}
Unusual low water levels in the Sea of Galilee (Dead Sea Fault, Israel) have caused the recent exposure of submerged Late Pleistocene prehistoric sites and lacustrine sediments along the southern shores of the lake. The Ohalo II site is a large fisher-hunter-gatherers camp with in-situ brush hut floors, hearths, and a human grave. The site is radiometrically dated by 25 charcoal dates to 19,430 BP (average, uncalibrated). The archaeological remains include quantities of excellently preserved organic remains. These would not have been preserved without a rapid rise of lake level immediately after the occupation, covering the remains with silts and sand. Recently a concentration of eight tree trunks were found about $1.5 \mathrm{~km}$ south of Ohalo II, of which five trunks were identified as Salix species and dated as a single accumulation at about 16,100 BP. The trunks, too, had to be submerged quickly together to ensure excellent preservation. The camp and the trunks were found at $-212 /$ $-213 \mathrm{~m}$, almost $4 \mathrm{~m}$ below modern high water levels. We suggest that the finds represent two separate episodes of deposition during low lake levels, almost 3,000 radiocarbon years apart, each followed by an abrupt water rise. It is possible that climatic changes caused the observed fluctuations, though earthquakes (blocking or lowering the Jordan outlet, for example) cannot be ruled out.
\end{abstract}

\section{INTRODUCTION}

The study of global climatic changes during and immediately after the last glaciation is based on investigations from a wide range of sources. The most commonly cited ones are deep sea and ice cores, though other marine sediments and formations are also incorporated in the reconstruction of past climates. Terrestrial sources provide additional data, and of these inland lake sediments contribute to regional climate reconstruction. It is within this framework that new data from the Sea of Galilee, Dead Sea Fault (Israel) are presented here.

During the last decade severe droughts caused dramatic lake level changes in the Sea of Galilee. During these years, Late Pleistocene submerged archaeological sites and lacustrine sediments were temporarily exposed and for the first time visible to archaeologists and geologists. Fieldwork has concentrated on the excavation of Ohalo II, an in-situ Late Pleistocene fisher-hunter-gatherers camp, and a thorough archaeological/geological survey and study of the newly exposed beaches (Figure 1). This paper presents new radiometric dates of Late Pleistocene finds, correlates them with past lake level changes, and points to possible environmental changes during and immediately after the Last Glacial Maximum. All radiocarbon dates in this paper are uncalibrated (calibrated dates will be indicated).

\section{THE SEA OF GALILEE BASIN}

The Dead Sea Rift is a plate boundary that traverses the Red Sea and extends to the Zagros-Taurus convergence. Sinistral displacement of the Arabian plate along the transform started in the Neogene and is about $100 \mathrm{~km}$ with respect to the Sinai plate (Garfunkel 1981).

The Sea of Galilee is an intermediate lake that occupies one of the morphotectonic depressions within the Dead Sea Fault. The lake is almost oval in shape, with maximum dimensions of

\footnotetext{
${ }^{1}$ Zinman Institute of Archaeology, Haifa University.

${ }^{2}$ Department of Archaeology, The Hebrew University of Jerusalem

${ }^{3}$ Environmental Science and Energy Research, Weizmann Institute

${ }^{414} \mathrm{C}$ AMS Laboratory, Aarhus University

${ }^{5}$ Department of Botany, The Hebrew University of Jerusalem

${ }^{6}$ Department of Geophysics and Planetary Sciences, Tel Aviv University, Ramat Aviv, Tel Aviv 96978, Israel
}

(C) 2001 by the Arizona Board of Regents on behalf of the University of Arizona

Near East Chronology: Archaeology and Environment. RADIOCARBON, Vol 43, Nr 3, 2001, p 1167-1178

Proceedings of the 17th International ${ }^{14} \mathrm{C}$ Conference, edited by $\mathrm{H} \mathrm{J}$ Bruins, I Carmi, and E Boaretto 
$20 \times 12 \mathrm{~km}$, and a maximum depth of $46 \mathrm{~m}$. The upper Jordan River drains the Hula basin into the Sea of Galilee and forms the most important inlet to the lake. The lower Jordan River is the only natural outlet draining the Sea of Galilee to the lowest erosion base level in the world- the Dead Sea, now at about $-410 \mathrm{~m} \mathrm{msl}$.

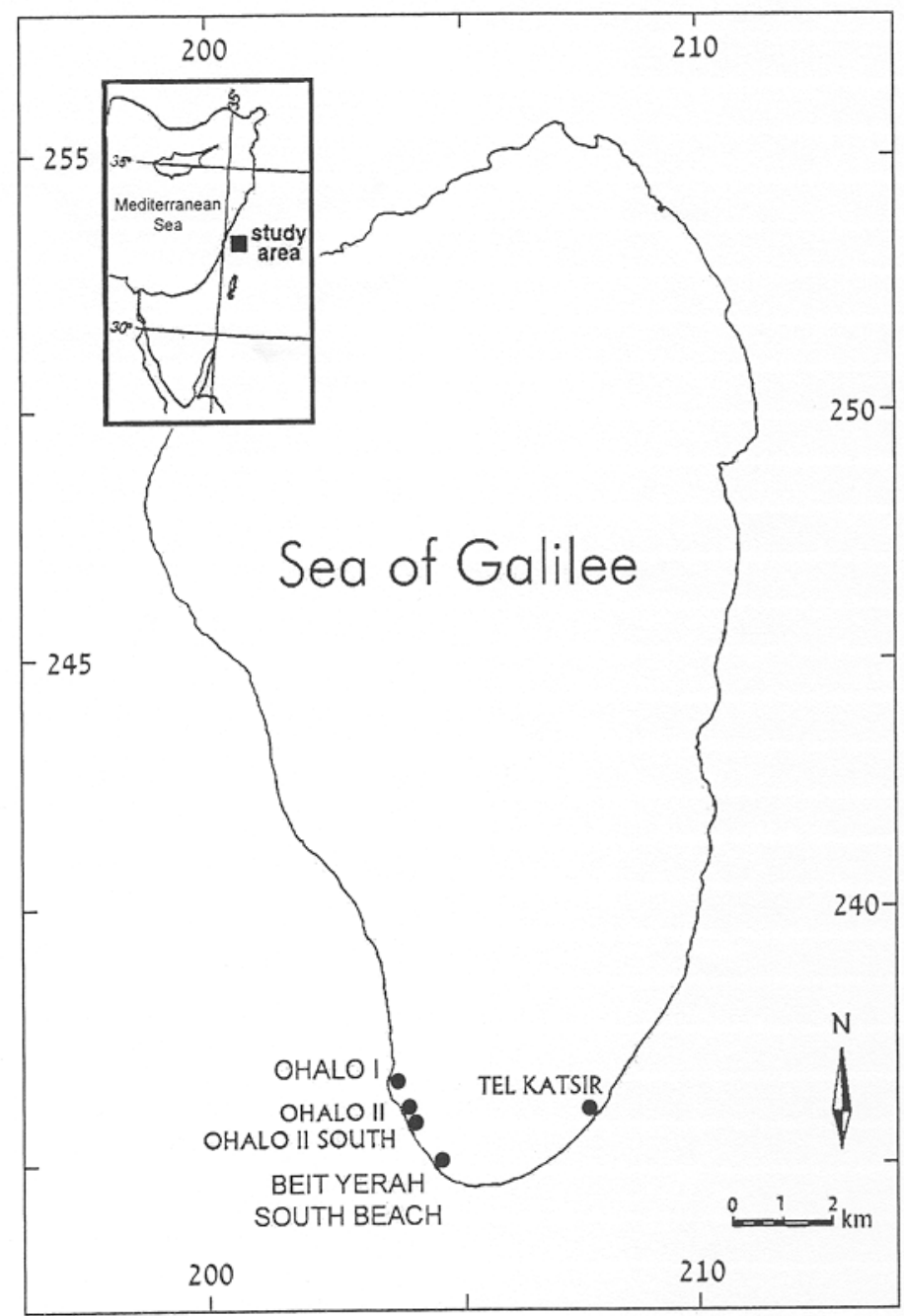

Figure 1 Location of dated sites: Ohalo II-Ohalo II South prehistoric camp, Beit Yerah Southern Beach (with Salix trunks and lacustrine sediments), and Tel Katsir Beach (with lacustrine sediments). Note that Ohalo I is a location of surface finds attributed to the Late Pleistocene but not radiometrically dated.

The Sea of Galilee was formed in a composite basin, the southern part of which is a graben (BenAvraham et al. 1996) filled by more than a four-km-thick accumulation of evaporites, igneous, and clastic rocks (Marcus and Slager 1985). In the Late Quaternary the graben was covered by the brackish to hyper saline Lake Lisan, in which marly lacustrine sediments and clastics of the Lisan Formation (Fm.) were deposited. This lake was more than $200 \mathrm{~km}$ long, extending southward beyond the 
current Dead Sea (Neev and Emery 1967; Begin et al. 1974). Towards the end of the Pleistocene the Lisan Lake shrank and retreated from the northern part of the lower Jordan Valley. According to bores in the northern part of the lake (Horowitz 1979), from about 19-18 ka BP dark colored silts and clays of freshwater Tabgha Fm. were deposited in the Sea of Galilee.

The southern area of the lake is much shallower and the slope of the bottom is relatively gentle. It has been suggested that this area was formed by an erosional process that caused the southward retreat of the original shore; the rate of the modern retreat has been measured, reaching up to $0.5 \mathrm{~m} /$ yr before protection measures were undertaken (Ben-Arieh 1965).

The lake region was tectonically active and folded structures as well as active faults have been detected along the margins and at the center of the lake (Ben-Avraham et al. 1996). A steep underwater slope forming a discrete morphological step suggests a tectonic origin for the northern shores of the Sea of Galilee. Evidence for faults, landslides, and powerful floods in the northern part of the basin has been provided recently. Several of these were radiometrically dated (from Upper Pleistocene to Late Holocene: Shroder et al. 1999; Marco et al. 2000).

During the 20th century the water surface was usually at $-209 /-210 \mathrm{~m}$ (below msl) when the lake was full. However, the reconstruction of pre- 20th century water levels on the basis of direct geomorphological evidence is rendered difficult due to a late rocky coverage of beaches with potential indications of past water levels. Furthermore, these beaches were submerged during most of the 20th century (they were exposed only a few times for several months each). However, the southern perimeter of the lake is mostly devoid of rocks and thus is more suitable for geo-archaeological prospecting.

Between 1989 and 1999 the water level of the lake dropped dramatically five times (due to severe droughts and heavy pumping to the national water conduit). In each event the drop was of a 3-4 m magnitude. The first evidence for Pleistocene remains was found in a surface scatter of flint implements. The site was named Ohalo I (Figure 1) and the artefacts were tentatively ascribed to the Epipalaeolithic Geometric Kebaran Culture, about 14,500-12,800 BP (Bar-Yosef and Nadel 1988).

More recently further widespread evidence for somewhat earlier human occupation of the shores of the Sea of Galilee derives from an ongoing project at the nearby in-situ site of Ohalo II. Neither earlier nor contemporaneous in-situ sites are known from the current beaches of the lake.

\section{THE OHALO II CAMP}

Excavations at the Ohalo II camp revealed the remains of six brush huts, a human grave, hearths, and other installations (Figures 1, 2; Nadel 1996; Nadel and Hershkovitz 1991). The site is located at $212 /-213 \mathrm{~m}$ and thus usually is submerged in modern times. It was excavated during the extremely low lake levels of 1989-91 and 1999. Organic remains in particular are excellently preserved and some are the oldest of their kind ever found. These include the bases of brush hut walls (Nadel and Werker 1999) and the fragments of cords (Nadel et al. 1994). Also, the largest Late Pleistocene assemblage of charred seeds/fruit was found on the floors and in the hearths. A sample of about 40,000 specimens has been studied and identified so far (Kislev et al. 1992; Simchoni 1997). The 29 charcoal dates from 10 separate loci range from about 18,000-21,000 BP, with an average for 25 dates of 19,430 $\pm 770 \mathrm{BP}$ (Nadel et al. 1995). The archaeological remains suggest a relatively brief overall occupation of the site and definitely not in the order of thousands of ${ }^{14} \mathrm{C}$ years.

Sections through the archaeological features and adjacent geological trenches provide a detailed stratigraphy. The relevant data here include three major points. First, all the archaeological features (grave, brush hut floors, etc.) are in situ on fine sands/silts that are a local facies of the Lisan Fm. 


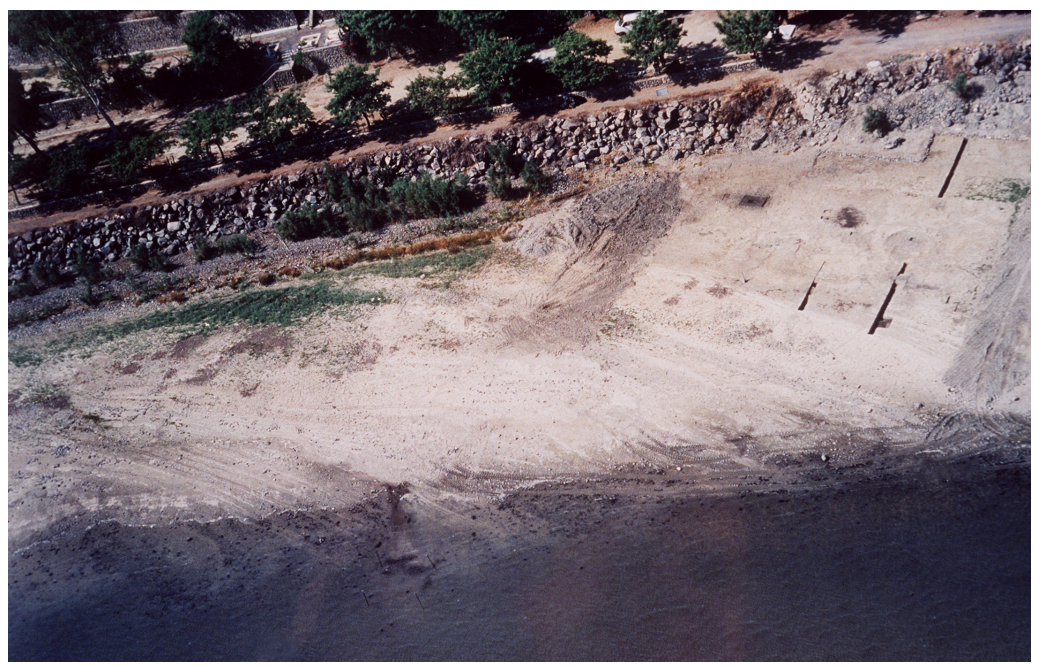

Figure 2 Aerial photo of Ohalo II camp during excavations, looking west. The dark oval areas between the narrow trenches are floors of in situ Late Pleistocene brush huts. Sediments at bottom left are post-occupation. Water level is about $-213 \mathrm{~m}$ (photo by Arik Baltinester).

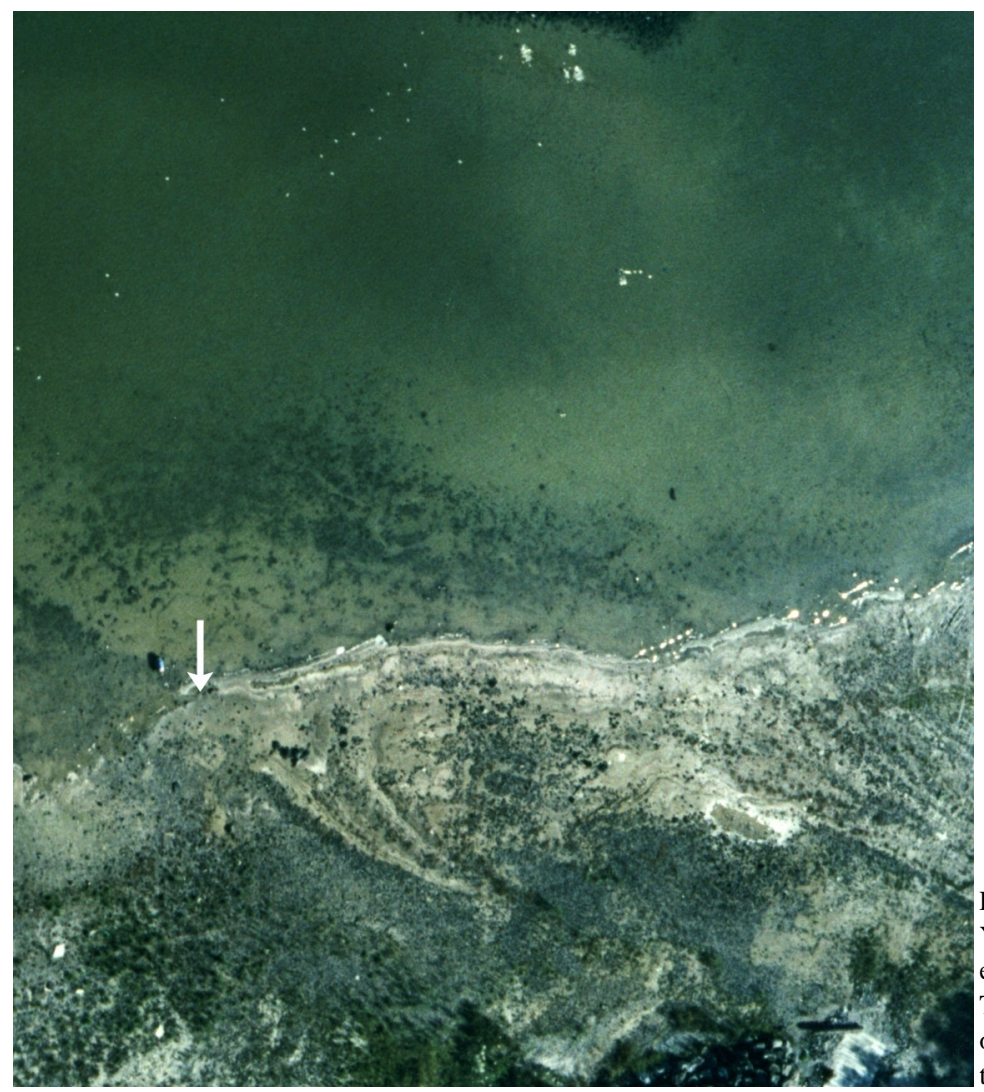

Figure 3 Aerial photo of Beit Yerah Southern Beach, looking east. Water level is about $-213 \mathrm{~m}$. The arrow points to the location of the trunks (photo by Arik Baltinester). 
Accordingly, the camp was occupied after the retreat of the Lisan from this basin. A wealth of fish bones and plant remains found in sealed archaeological contexts suggest an adjacent coeval body of fresh water (Nadel et al. 1994). This, most probably, represented the earliest phase of the present Sea of Galilee. Second, only some of the archaeological features are exposed (and thus found and excavated). Others are still completely covered by layers of fine-grained lacustrine sediments and have only been identified in trench sections. These layers dip eastward from the center of the site. One of the post-occupation layers was dated in the current study to $15,430 \pm 10 \mathrm{BP}$ (Table 1). It should be noted that this was not the earliest post-occupational layer. It appears that subsequent small-scale tectonic uplift has caused the exposure of some archaeological and later lacustrine layers and the dip of the rest. At any rate, this date indicates that lacustrine sediments were still being deposited after the occupation, at the very end of the Pleistocene.

The third point relates to phases of occupation at the site. The various in situ archaeological features cluster into three depositional cycles. In other words, there were at least three episodes of occupation, separated by inundations. The occupational phases were short, according to thickness of layers and extremely high similarities in material culture remains. The in-between sediments reflecting inundations are less than $50 \mathrm{~cm}$ thick. Since the beginning of the project, we observed that in this part of the lake a deposition of 10-20 cm layer of fine sediment can occur in one season (in shallow waters, less than one meter deep). It should also be pointed out that charcoal dates from all loci are inseparable into the distinct phases identified through the sedimentological sequence. It is suggested that the three cycles were short. Each inundation deposited enough sediment to immediately protect the archaeological features, and by the end of the last cycle water level remained high and long enough to cover the entire area with thicker layers.

The camp covers a contiguous area of at least 2,000 $\mathrm{m}^{2}$. However, during the 1999 field season further finds were discovered some $130 \mathrm{~m}$ to the south of the central excavation area (Ohalo II South). Here, at an elevation of about $-213 \mathrm{~m}$ and in an identical geological setting, flint artefacts, and bones were found that appear to be identical to the main area finds.

Dating of samples from Ohalo II South has provided analogous results to those at Ohalo II, with dates of $19,550 \pm 250 \mathrm{BP}$ and 19,940 $\pm 210 \mathrm{BP}$ for the occupation, and 12,830 $\pm 80 \mathrm{BP}$ for the overlying lacustrine layers. The two archaeological dates fall within the range of the Ohalo II dates, though the average of the latter is somewhat younger. However, both parts of the Ohalo II site indicate contemporaneous occupation and a cover by lacustrine sediments. In both cases the post-occupation dates derive from much later layers, and not from the immediate post-occupation ones. It is thus clear that the deposition over the area continued for several millennia, until the very end of the Pleistocene.

It should be stressed that both areas of the site could not have been preserved without anaerobic conditions created by a rapid rise in water level and the deposition of fine sediments. Prolonged exposure to the open air and/or a catastrophic cover by floods would have caused severe damage and leave a site very different from the one we know. Accordingly, two conclusions are inferred: a) the Ohalo II site was occupied when the lake water level was lower than $-213 \mathrm{~m}$, and $\mathrm{b}$ ) there was a rapid and substantial rise immediately following the occupation episodes during which fine sediments were deposited over the entire site and covered and protected the remains. The 15,430 BP and $12,830 \mathrm{BP}$ dates reflect subsequent deposition of sediments and not the speedy cover of the site. So far, Ohalo II is the only Late Pleistocene site along the Sea of Galilee shores where in-situ human occupation is radiometrically dated and directly correlated to water level changes and depositional conditions. 
Table $1{ }^{14} \mathrm{C}$ dates from the southern Sea of Galilee.

\begin{tabular}{|c|c|c|c|c|c|}
\hline Lab nr & Collection site & Type & $\begin{array}{l}\text { Age } \pm 1 \sigma \\
(\mathrm{BP})\end{array}$ & $\mathrm{m}$ bsl & $\begin{array}{l}\delta^{13} \mathrm{C} \\
(\% o)\end{array}$ \\
\hline RTA-3275 & Ohalo II, post-occupation & $\begin{array}{l}\text { Stem of } \\
\text { reed }\end{array}$ & $15430 \pm 110$ & -212.5 & -28.0 \\
\hline RTA-3276 & Ohalo II south, post-occupation & $\begin{array}{l}\text { Plant } \\
\text { material }\end{array}$ & $12830 \pm 80$ & -212.5 & -26.6 \\
\hline RT -3277 & Tel Katsir Beach & $\begin{array}{l}\text { Organic } \\
\text { material }\end{array}$ & $21020 \pm 100$ & -212.5 & -27.4 \\
\hline RT-3531 & Beit Yerah Southern Beach 1 & Wood & $15400 \pm 160$ & -213 & -28.7 \\
\hline RT -3532 & Beit Yerah Southern Beach 2 & Wood & $15860 \pm 160$ & -213 & -28.2 \\
\hline RT -3533 & Beit Yerah Southern Beach 3 & Wood & $16090 \pm 160$ & -213 & -28.6 \\
\hline RT-3534 & Beit Yerah Southern Beach 4 & Wood & $16020 \pm 160$ & -213 & -27.9 \\
\hline RT -3535 & Beit Yerah Southern Beach 5 & Wood & $16410 \pm 160$ & -213 & -28.5 \\
\hline RT-3536 & Beit Yerah Southern Beach & $\begin{array}{l}\text { Organic } \\
\text { material }\end{array}$ & $16320 \pm 160$ & -212 & -28.2 \\
\hline RT-3537 & Ohalo II South, prehistoric camp & Charcoal & $19550 \pm 250$ & -212.5 & -13.0 \\
\hline RTA-3539 & Ohalo II South, prehistoric camp & Charcoal & $19940 \pm 210$ & -213 & -22.3 \\
\hline
\end{tabular}

\section{THE SOUTHERN BEIT YERAH AND TEL KATSIR BEACHES}

Another important location for understanding of the lakes' history was discovered about $1.5 \mathrm{~km}$ south of Ohalo II, near the current outlet of the Jordan River (Figures 1, 3). First, still submerged when water level was $-212.30 \mathrm{~m}$, were several segments of what look like a part of an ancient harbor or dock. If so, they probably date to the Hellenistic/Roman/Byzantine time span. This is because similar installations found around the lake were dated to this period (Nun 1991). However, the new finds are topographically lower $(2-3 \mathrm{~m})$ than any contemporaneous archaeological remains around the lake. Accordingly, they could reflect post Hellenistic/Roman/Byzantine vertical displacement of this part of the beach.

Pleistocene remains were also discovered at this beach. These include eight tree trunks embedded in lacustrine sediments at heights between -212.80 and -213.20 , within an area of about $100 \mathrm{~m}^{2}$ (Figure 4). However, most were concentrated over some $50 \mathrm{~m}^{2}$ (excluding trunk $\mathrm{nr} 1$ ). The trunks lay horizontally in various orientations and the excavated portions had no branches or roots attached to them or near them. All are excellently preserved, with diameters of $20-40 \mathrm{~cm}$ and lengths of $1 \mathrm{~m}$ or more.

Sampled sections from five trunks indicated that all are, apparently, willow trees (Salix species). Two Salix species currently grow on riverbanks and lakeshores in the Jordan Valley, but it is impossible to distinguish between them by anatomical sections of the trunks.

The same five logs were recently dated with all ranging between $15,400 \pm 160 \mathrm{BP}$ and $16,410 \pm 160$ $\mathrm{BP}$ (Table 1). The average of the trunks $2,3,4,5$ is $16,100 \pm 80 \mathrm{BP}$. Only trunk $\mathrm{nr} 1$ is relatively younger and thus excluded from the average. It is notable that it was found somewhat separated from the other trunks ( $5 \mathrm{~m}$ away), though still in the same lacustrine layer.

The concentration of the trunks in one place, in horizontal positions, and with similar dates is taken to reflect a single event, or at least a brief period of deposition on the beach. We believe that this depositional episode reflects one year, and, at any rate, not more than several years occurring about $16,100 \pm 80 \mathrm{BP}$. If the period had been longer (on the scale of hundreds of years) the earlier trunks 


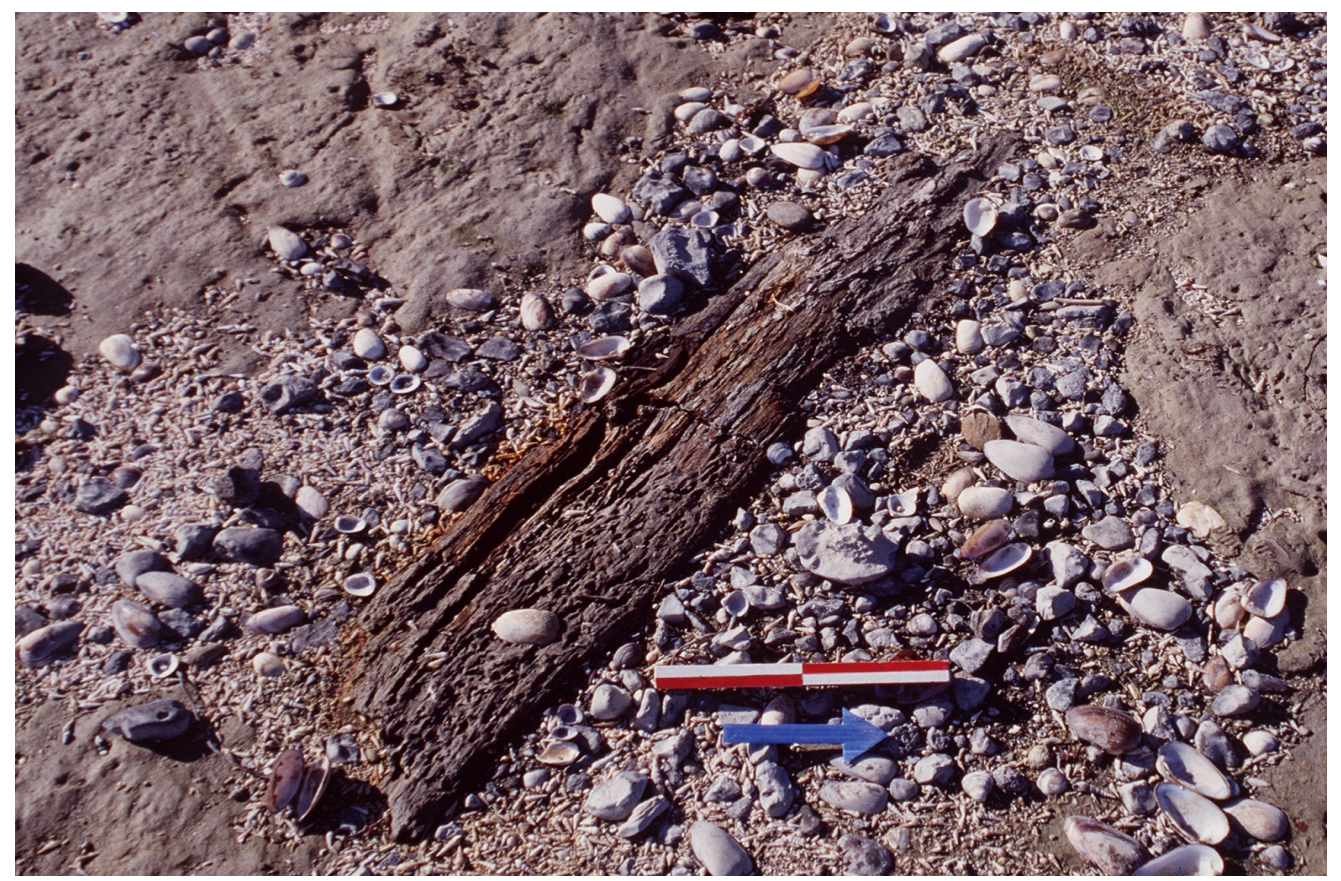

Figure 4 A Salix trunk embedded in Late Pleistocene clay sediments at Beit Yerah Southern Beach. Scale bar is $20 \mathrm{~cm}$..

would probably have decomposed before the later ones would have been deposited. Thus, the facts that they are concentrated (and not visible elsewhere on the beach) and excellently preserved reflect one short depositional episode followed by an immediate water level rise. It is also noteworthy that the trunks do not look like the remains of natural bank vegetation. The absence of other tree parts and other species, and the presence of a gazelle horn core and isolated bones might indicate human intervention here. This can only be tested in future excavations (water levels permitting).

Adjacent to these logs, lacustrine layers form a shore bar. Some of the layers dip steeply (up to $60^{\circ}$ ), and organic material was collected from one (Figure 5). This was dated to 16,320 $\pm 90 \mathrm{BP}$, which is very close to those obtained from the willow trunks. It appears that the trees were deposited during or immediately after the deposition of the dated lacustrine layers.

A systematic survey of this area of the beach was conducted and many tens of basalt implements were collected from the surface. These include pestles, handstones, and bowls (most of which are broken), though the finds are not chronologically diagnostic.

The entire southeastern shore of the lake, at heights of -212/-213 m, is composed of fine lacustrine sediments. They look very similar in color and composition to the southwestern exposed sediments. Here, too, dipping structures similar to the one recorded near the willow trees were visible. Furthermore, organic material was detected in some places (Figure 6). An identification attempt was unsuccessful, but the remains look like a jumble of leaves and stems that underwent deformation processes, probably due to the pressure of overlying sediments. One sample (from Tel Katsir Beach) was dated to 21,020 $\pm 100 \mathrm{BP}$. Thus, the exposed southeastern sediments are all of Late Pleistocene origin, more or less contemporaneous to the Ohalo II camp or the immediate underlying strata. 


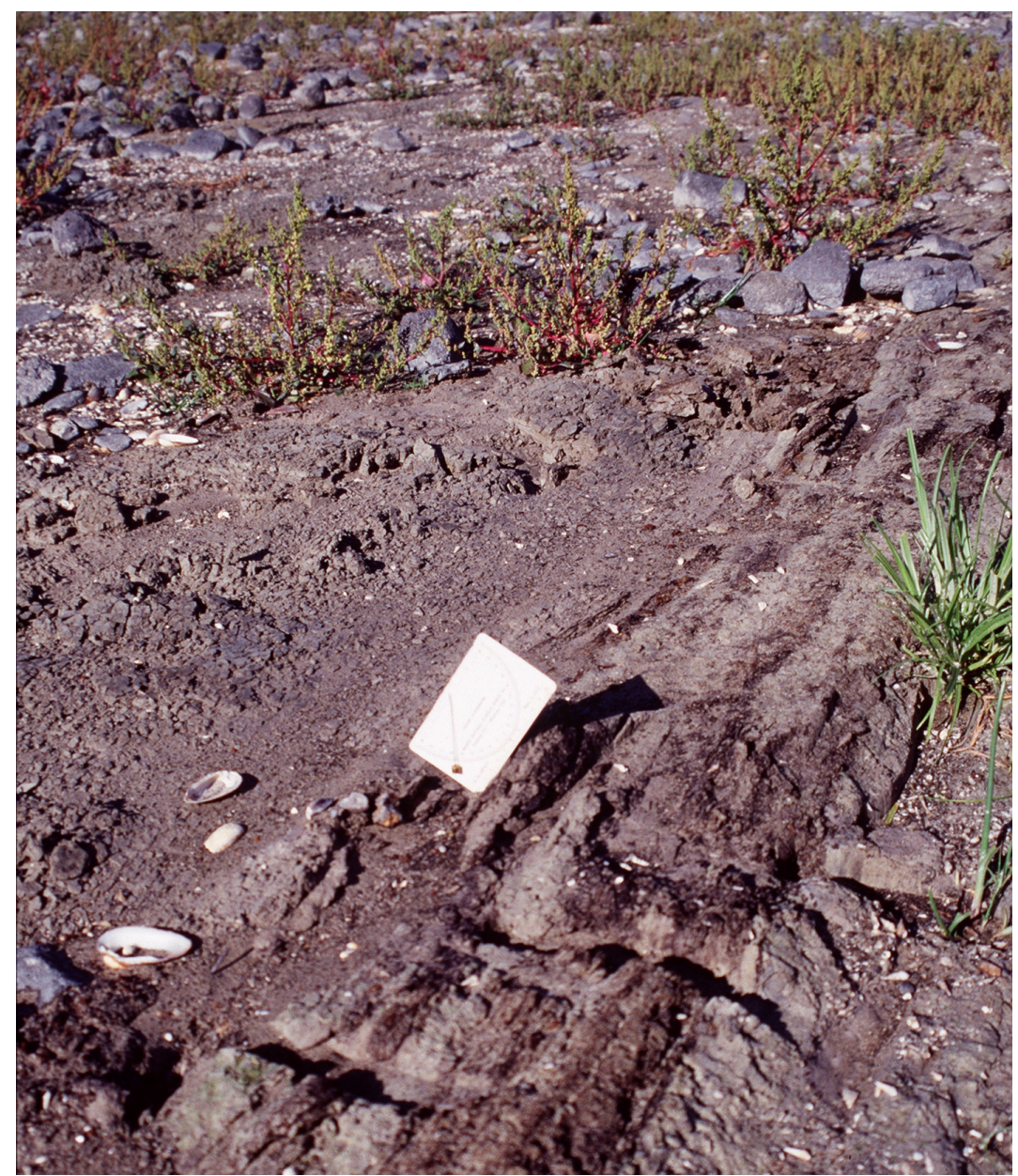

Figure 5 A close-up view of in-situ organic matter in steeply dipping lacustrine sediments near the Salix tree trunks looking northeast (Beit Yerah southern Beach)

\section{DISCUSSION}

The submerged southern shore of the Sea of Galilee is composed of Late Pleistocene sediments. They have been radiometrically dated in four different locations, where in-situ organic materials were excellently preserved (Ohalo II, Ohalo II South, Beit Yerah Southern Beach, and Tel Katsir Beach). Two of these locations represent human camps on the Lisan Fm (the trees may also reflect human presence, though direct evidence is lacking). Systematic archaeological surveying of the beaches at times of low water levels around the Sea of Galilee has thus far revealed Late Pleistocene human occupations only at the southwest end of the lake, at the adjacent sites of Ohalo I and Ohalo II (Nadel 1993). The difference between the southern and northern shores of the lake in terms of Late Pleistocene human sites is partially explained by the fact that the Jordan River and other active wadis continuously cover the northern shores with sediments.

Two similar, sequential environmental events are recorded in the data presented here. The first is the Ohalo II complex, where a well dated prehistoric camp is excellently preserved. The remains indicate about three cycles of human occupations and rapid inundations within a general transgressive 


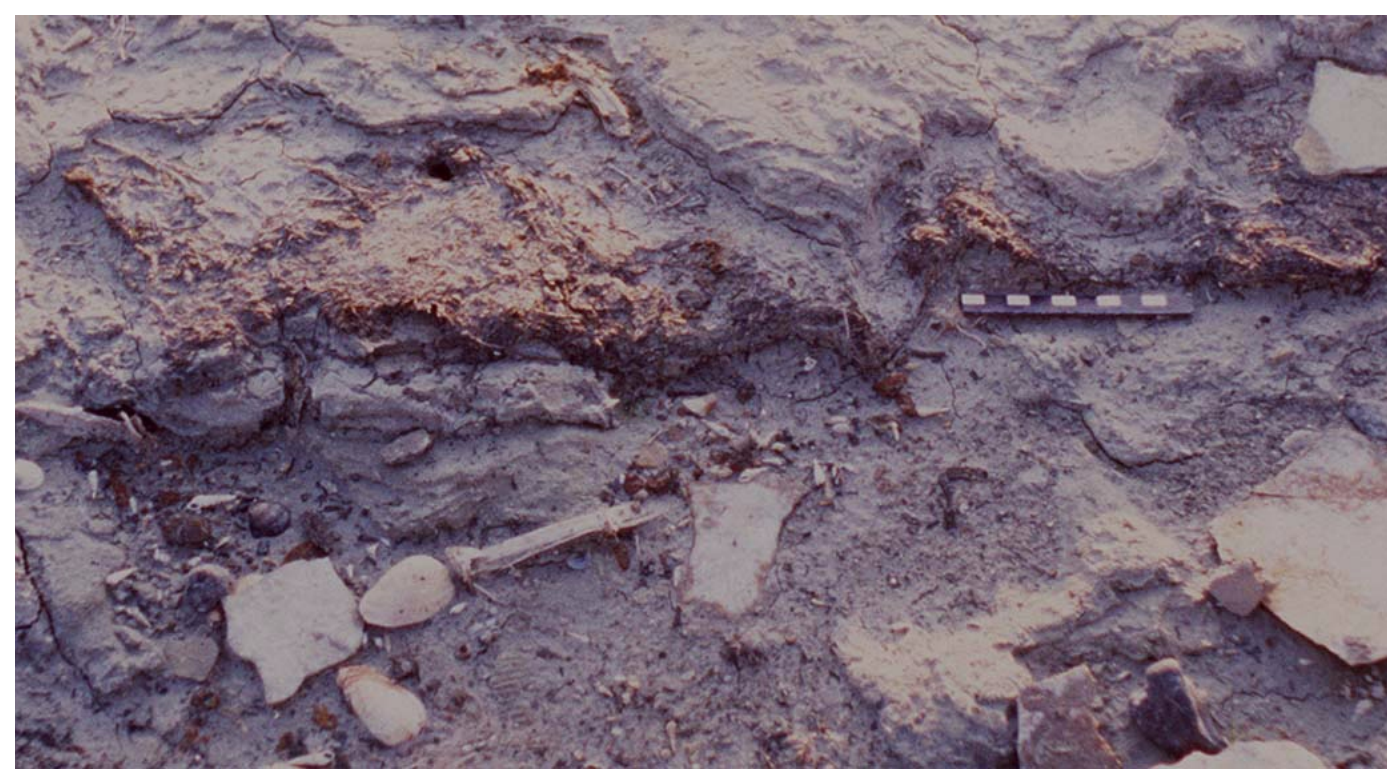

Figure 6 A close-up view of in-situ organic matter in lacustrine sediments at Tel Katsir Beach. Scale bar is $10 \mathrm{~cm}$.

trend. Each water level rise deposited a low-energy cover over the abandoned camp. Thus, the site reflects a time of short water level fluctuations around the $-213 \mathrm{~m}$ level, and then a high stand long enough to deeply cover the area by additional sediments. Such a rise is evident in the finely laminated layers covering both Ohalo II and Ohalo II South. This event is dated to about 19,500 BP.

The second event is the willow trees complex. At this location, trees were deposited on (or near) the lakeshore about 16,100 BP. Here, too, it is suggested that a quick water rise submerged the trees and caused their cover by layers of fine sediments.

The two groups of dates (about 19,430 $\pm 770 \mathrm{BP}$ and 16,100 $\pm 80 \mathrm{BP}$, corresponding to $23,850-$ 22,250 cal BP and 19,550-18,850 cal BP, respectively) represent two episodes of water level changes. They could have been caused by climatic changes at the end of the glacial period (the Ohalo II event) and the transitional glacial-interglacial period (the willow trees). The effects of the climatic events on water level changes could have been amplified by local hydrological and morphological conditions (e.g. sudden changes in water influx from the Upper Jordan).

Direct correlation of lake level changes to climatic fluctuations is only tentative. Indeed, global climatic fluctuations during the period discussed here are well established and it is reasonable to suggest that climate is the key factor controlling water levels. However, there are other factors to be considered. Seasonal rains or droughts could temporarily affect the lake water balance. Also, there is evidence for Pleistocene and Holocene tectonic deformations around the lake. Thus, water level changes could reflect a combination of several environmental and other events.

Site location analyses, combined with the geomorphologic and sedimentological evidence, suggest a major lowering of Lisan Lake by about 19,500 BP or a little earlier. This was probably the result of dry climatic conditions that prevailed between 22,000-19,000 BP (uncal. Horowitz 1978; Weinstein-Evron 1993). The lowering event was severe enough to cause the retreat of the Lisan from the Sea of Galilee basin. The morphotectonic depression that was formed in the Sea of Galilee area was 
filled by fresh water that supported large populations of fish (amply evident in the Ohalo II material remains). This was the occupation time of the Ohalo II camp (three phases of small-scale fluctuations). The camp was then completely abandoned, submerged, and gently, though quickly, covered by fine lacustrine sediments deposited by the rising lake level.

Later, about 16,100 BP, a similar episode of a low lake stand is evident about $1.5 \mathrm{~km}$ south at the location of the willow tree trunks embedded in fine lacustrine sediments, east of a shore bar. This bar marks a low lake stand. Interestingly, the Ohalo II camp was not affected by erosion during this second event of low stand. This indicates that by $16,100 \mathrm{BP}$ the Ohalo II site was already covered by protective sediments. This is in accordance with our model that shortly after occupation a layer of fine sediments was deposited over the site. In addition, this implies that the exposure of the archaeological remains postdates 16,100 BP Indeed, we believe this exposure was caused by a recent small-scale tectonic uplift of the Ohalo II area.

The most cited evidence for regional climatic changes during the late Pleistocene in the Levant comes from pollen studies (lake cores). The nearest core to the Sea of Galilee was extracted from Lake Hula, less than $50 \mathrm{~km}$ to the north. The relevant curve presents an arid and cold period at the time interval discussed here (25,000 BP-16,000 BP, uncal., Tsukada in Bottema and van Zeist 1981). Within this dry period, there are at least three short wetter events. Two of these could coincide with the Sea of Galilee events, dating limitations making this tentative at best.

A higher resolution of dated changes was recently published for the Soreq Cave speleothems (Judean Hills, Israel). According to this study, arid conditions prevailed in the eastern Mediterranean area during the period of 25,000 cal BP and 17,000 cal BP (Bar-Mathews et al. 1997, Bar-Mathews et al. 1999; Kaufman et al. 1998). The period was also characterized by low precipitation and a low evaporation/precipitation ratio. Detailed analyses showed that there were some identified climatic fluctuations in this period. In particular, there are many fluctuations around 22,000 BP-19,000 BP. Two of these could correspond to the lake level changes attested by the data presented here.

On a global scale, there is ample isotopic evidence for climatic changes dated to the time period discussed here. Of interest are the data from Lake Suigetsu (Japan) laminated sediments that provide a well-dated sequence with fluctuations almost coinciding with the two events in the Sea of Galilee (Kitagawa and van der Plicht 1998). Recent publication of a marine sediment core from the Iberian margin presented a high-resolution paleoclimatic record (Bard et al. 2000). Of direct relevance is the fact that the two Sea of Galilee events fall well within two global cold phases documented there. Furthermore, well dated climatic fluctuations are available for North Atlantic ice cores and sediments, as well as for lower latitudes affected by ocean circulation (see Neftel et al. 1988; McCabe and Clark 1998; Marchitto et al. 1998 and references therein). In these examples several fluctuations begin at about 24,000 BP (cal.) and a marked though short cooling event is evident about 2,500-3,000 years later. This corresponds well with the sequence presented here for the Sea of Galilee.

\section{CONCLUSIONS}

The Ohalo II camp and the willow trunks represent two periods of water level lower than $-213 \mathrm{~m}$. The first, at about 19,500 BP was followed by an abrupt lake level rise submerging the site and preserving the wide range of organic remains. The second, at about 16,100 BP was also followed by an immediate water rise. In both cases the evidence is found at the same absolute height, though they are not contemporaneous. It is therefore inferred that the earlier site was already well covered by lacustrine sediments when the willow trunks were deposited on the shore. 
There are two plausible ways of explaining these events: one involving climatic fluctuations and the other tectonic deformation. Yet, there is no unequivocal evidence to directly support either interpretation. There are, indeed, global climatic fluctuations more or less contemporaneous to the Sea of Galilee events. However, earthquakes could have easily affected water levels. There is ample evidence around the lake for tectonic deformations, with dates ranging from Late Pleistocene to Late Holocene (Marco et al. 2000). Similar events could have temporarily blocked the entrance and/or exit of the Jordan River, or have caused small-scale vertical movements of certain beach areas. Only additional fieldwork, providing dated evidence for direct correlations between tectonic deformations and lake level changes may shed more light on this aspect of the lakes' history.

\section{ACKNOWLEDGMENTS}

The Ohalo II-Sea of Galilee project was kindly supported by the Irene Levi Sala CARE Archaeological Foundation, The Jerusalem Center for Anthropological Studies, the LSB Leakey Foundation, the M Stekelis Museum of Prehistory in Haifa, the National Geographic Society, the MEFCAF Fund, and the Israel Antiquities Authority. We wish to thank Nigel Goring-Morris for reading the manuscript and for his useful suggestions. The map was prepared by Andrey Yaroshevich.

\section{REFERENCES}

Bard E, Rostek F, Turon JL, Gendreau S. 2000. Hydrological impact of Heinrich events in the subtropical northeast Atlantic. Science 289:1321-24.

Bar-Mathews M, Ayalon A, Kaufman A. 1997. Late Quaternary paleoclimate in the eastern Mediterranean region from stable isotope analysis of speleothems at Soreq Cave, Israel. Quaternary Research 47:15568.Bar-Mathews M, Ayalon A, Kaufman A, Wasserburg GJ. 1999. The eastern Mediterranean paleoclimate as a reflection of regional events: Soreq Cave, Israel. Earth and Planetary Science Letters 166:85-95.

Bar-Yosef O, Nadel D. 1988. Ohalo-a prehistoric site in the Sea of Galilee. Mitekufat Haeven, Journal of the Israel Prehistoric Society 21:87-94.

Begin ZB, Ehrlich A, Nathan Y. 1974. Lake Lisan, the Pleistocene precursor of the Dead Sea. Ministry of Commerce and Industry, Geological Survey, Bulletin nr 63, Jerusalem.

Ben-Arieh Y. 1965. The shift of the outlet of the Jordan at the southern shore of Lake Tiberias. Palestine Exploration Quarterly: 54-65.

Ben-Avraham Z, Ten Brink U, Bell R, Reznikov M. 1996. Gravity field over the Sea of Galilee: evidence for a composite basin along a transform fault. Journal of Geophysical Research 101(B1):533-44.

Bottema S, van Zeist W. 1981. Palynological evidence for the climatic history of the Near East 50,000-6,000 BP. In: Cauvin J, Sanlaville P, editors. Prehistoire $d u$ Levant. Paris: CNRS. p 111-32.

Garfunkel Z. 1981. Internal structure of the Dead Sea transform (rift) in relation to plate kinematics. Tectonophysics 80:80-108.

Horowitz A. 1978. The Quaternary evolution of the Jordan Valley: In: Serruya C, editor. Lake Kinneret, monografiae biologicae 32:33-43.
Horowitz A. 1979. The Quaternary of Israel. New York: Academic Press.

Kislev ME, Nadel D, Carmi I. 1992. Epipalaeolithic $(19,000$ BP) cereal and fruit diet at Ohalo II, Sea of Galilee, Israel. Review of Palaeobotany and Palynology 73:161-6.

Kitagawa H, van der Plicht J. 1998. Atmospheric radiocarbon calibration to $45,000 \mathrm{BP}$ : late glacial fluctuations and cosmogenic isotope production. Science 279:1187-90.

Marchitto TM, Curry WB, Oppo DW. 1998. Millennialscale changes in North Atlantic circulation since the last glaciation. Nature 393:557-61.

Marco S, Rockwell T, Heimann A, Agnon A, Ellenblum R. 2000. Historical earthquakes deformations revealed by 3-D trenching on Dead Sea Transform. In: Okumura K, Takada K, Goto H, editors. Active fault research for the new millennium. Proceedings of the Hokudan International Symposium and Scholl on Active Faulting. Hokudan Co. Ltd. p 261-3.

Marcus E, Slager J. 1985. The sedimentary-magmatic sequence of the Zemah-1 well (Jordan-Dead Sea Rift, Israel) and its emplacement in time and space. Israel Journal of Earth Science 34:1-10.

McCabe AM, Clark PU. 1998. Ice-sheet variability around the North Atlantic Ocean during the last deglaciation. Nature 392:373-7.

Nadel D. 1993. Submerged archaeological sites on the shores of Lake Kinneret, Israel. 'Atiqot (English Series) XXII:1-12.

Nadel D. 1996. The organization of space in a fisherhunter-gatherers camp at Ohalo II, Israel. In: Otte M, editor. Nature et Culture, Colloque de Liege. Liege: E.R.A.U.L. 68. p 373-88.

Nadel D, Hershkovitz I. 1991. New subsistence data and 
human remains from the earliest Levantine Epipalaeolithic. Current Anthropology 32(5):631-5.

Nadel D, Danin A, Werker E, Schick T, Kislev ME, Stewart K. 1994. 19,000-years-old twisted fibers from Ohalo II. Current Anthropology 35(4):451-8.

Nadel D, Carmi I, Segal D. 1995. Radiocarbon dating of Ohalo II: archaeological and methodological implications. Journal of Archaeological Science 22(6):81122.

Nadel D, Werker E. 1999. The oldest ever brush hut plant remains from Ohalo II, Jordan Valley, Israel (19,000 BP). Antiquity 73 (282):755-64.

Neev D, Emery KO. 1967. The Dead Sea. Bulletin of the Geological Survey of Israel 41. Jerusalem.

Neftel A, Oeschger H, Staffelbach T, Stauffer B. 1988. $\mathrm{CO}_{2}$ record in the Byrd ice core 50,000-5,000 BP. Nature 331:609-11.

Nun M. 1991. The Sea of Galilee. Water levels, past and present. Kibbutz Ein Gev: Tourist Department and Kinnereth Sailing Co.

Shroder JF, Bishop MP, Kornwell KJ, Inbar M. 1999. Catastrophic geomorphic processes and Bethsaida archaeology, Israel. In: Arav R, Freund RA, editors. Bethsaida, a city by the north shore of the Sea of Galilee. Volume 2. Truman State University Press.

Simchoni O. 1997. Reconstruction of the landscape and human economy 19,000 BP in the Upper Jordan Valley by the botanical remains found at Ohalo II. [Unpublished PhD Thesis, Bar-Ilan University, Ramat Gan]. In Hebrew.

Weinstein-Evron M. 1993. Palaeoecological reconstructions of the Upper Palaeolithic in the Levant. In: Pavuk $\mathrm{J}$, editor. Actes du XIIe Congres International des Sciences Prehistoriques et Protohistoriques. Bratislava. $\mathrm{p}$ 259-70. 